\title{
JACEK STOCHEL
}

Uniwersytet Marii Curie-Skłodowskiej

ORCID: 0000-0002-2685-4296

\section{Przebudowa systemu generacji sil do misji Narodów Zjednoczonych. Próba utrzymania zdolności do realizacji mandatów}

\author{
Rebuilding the United Nations force generation system. \\ An attempt to maintain capabilities to implement mandates
}

UN Peacekeeping Operation as a tool of United Nations still play a vital role on restoring peace and security in the World. Due to the current conflicts, the role and scope of UN peacekeeping missions mandated tasks have changed significantly. Nowadays, they are not only an instrument of keeping the peace between states after conflict but also responsible for building the state structures, reform security system or promotion of human rights. For the execution of present mandates, often beyond the military tasks, the generated forces must be capable to implement them. The lesson learned from the recent years has shown that United Nations peace operations have not been adopted fully to the current conditions. The force generation system was based on assumptions from the past and did not meet the existing expectations. Thus, the UN was obliged to create a new system that would face up to contemporary peacekeeping. This article presents challenges for UN peacekeeping and describes the activities of the UN Secretariat aimed at improving the process of generation of forces for peacekeeping missions in order to implement modern missions' mandates.

Keywords: peacekeeping, UN system, armed conflict, UN Security Council

Słowa kluczowe: operacje pokojowe, system Narodów Zjednoczonych, konflikt zbrojny, Rada Bezpieczeństwa Narodów Zjednoczonych

\section{Wstęp}

Operacje pokojowe Narodów Zjednoczonych (NZ) wciąż uważane są za jeden z najbardziej skutecznych mechanizmów stworzonych przez społeczność międzynarodową w celu redukowania zagrożeń dla pokoju i bezpieczeństwa. Efektywność tych działań zależy od współpracy między państwami oraz ich 
zaangażowania $\mathrm{w}$ prace NZ, jak również od strategicznego partnerstwa z organizacjami regionalnymi. Coraz większą uwagę zwraca się obecnie na współpracę z państwem, na terytorium którego prowadzona jest operacja pokojowa, przy poszanowaniu jego prawa do samostanowienia.

Klasycznym zadaniem misji pokojowych jest rozdzielanie zwaśnionych stron, nadzorowanie zawieszenia działań zbrojnych czy monitorowanie przestrzegania porozumień pokojowych ${ }^{1}$. Obecnie tworzone misje realizują jednak szerszy mandat. Jego zakres może obejmować polityczne wsparcie działań władz lokalnych w stabilizacji kraju, ochronę ludności cywilnej, wspieranie dialogu politycznego, działania na rzecz odtwarzania struktury władz państwowych, reformę sektora bezpieczeństwa czy promowanie i wspieranie działań na rzecz ochrony praw człowieka². Realizacja takiego mandatu wymaga wielopłaszczyznowego przygotowania sił pokojowych, co oznacza stawianie większych oczekiwań względem personelu kierowanego przez państwa do wykonywania zadań w ramach misji.

Zainteresowanie uczestnictwem w misjach NZ utrzymuje się na wysokim poziomie. Wykazują je zarówno państwa rozwijające się, jak i rozwinięte, których zaangażowanie zmniejszało się ze względu na udział w innych operacjach (w szczególności podejmowanych przez organizacje regionalne, jak NATO i UE), a obecnie wzrasta. Motywy udziału w misjach są różne. Wśród politycznych należy wymienić zdobywanie prestiżu poprzez uczestnictwo w realizacji globalnej polityki bezpieczeństwa, chęć zaznaczenia swojej pozycji w określonym rejonie świata, zaangażowanie sojusznicze w zamian za wsparcie w innych obszarach, wpływ na obsadę kluczowych stanowisk w misjach oraz strukturach NZ, dostęp do informacji o sytuacji w danym rejonie czy możliwość realizowania własnej polityki dzięki zasiadaniu w ważnych organach organizacji, jak Rada Bezpieczeństwa (RB). Obecność wojskowa lub policyjna umożliwia także współdziałanie państw, które w przyszłości może się przełożyć na rozwój współpracy gospodarczej³.

1 Zob. np. mandat misji UNTSO na Bliskim Wschodzie (rezolucja RB NZ nr 50 z 29 V 1948 r.), misji UNIFIL w Libanie (rezolucja RB NZ nr 425 i 426 z 19 III 1978 r.), misji UNDOF między Syrią a Izraelem (rezolucja RB NZ nr 350 z 31 V 1974 r.), misji UNMOGIP na granicy Indii i Pakistanu (rezolucja RB NZ nr 91 z 30 III 1951 r.): Resolutions, „United Nations Security Council” [online, dostęp: 1 IX 2019], dostępne w internecie: $<$ http://www.un.org/en/sc/documents/resolutions $>$.

2 Można do nich zaliczyć misje: MONUSCO w Kongu, MINUSCA w Republice Środkowoafrykańskiej czy MINUSMA w Mali. Zob. tamże.

3 A.J. Bellamy, P.D. Williams, Broadening the base of United Nations troop- and police-contributing countries, International Peace Institute, New York 2012 (Providing for Peacekeeping, 1). 
Celem niniejszego opracowania jest przedstawienie obecnego poziomu zaangażowania państw w misjach NZ, a także podejmowanych przez tę organizację procesów decyzyjnych i reform, których głównym dążeniem jest umożliwienie pełniej realizacji mandatu misji określonego przez RB poprzez właściwe generowanie sił do operacji.

\section{Obecny zakres zaangażowania}

Według staniu z 1 września 2019 r. w 14 misjach pokojowych NZ uczestniczyło ponad 100 tys. osób ze 124 państw ${ }^{4}$. Personel umundurowany stanowił 85951 żołnierzy i policjantów. Należy przy tym zaznaczyć, że gdyby brać pod uwagę jedynie 10 państw, które wysyłają największą liczbę żołnierzy i policjantów, to 40 proc. tego personelu pochodziłoby z państw Afryki i Azji. Zestawienie to otwiera Bangladesz, który wysyła 8420 żołnierzy i policjantów, zamyka natomiast Senegal z 2643 osobami. Łącznie Afrykańczycy i Azjaci tworzą ponad 80 proc. sił. Z państw europejskich najwyżej plasują się na liście Włochy, które wysyłają 1077 osób, co daje im 21 pozycję; Polska z 5 obserwatorami zajmuje natomiast miejsce $107^{5}$.

Pod względem liczby personelu spośród misji prowadzonych od wielu lat jedynie UNIFIL w Libanie dysponuje siłami przekraczającymi 10 tys. żołnierzy. Współczesne operacje, z nowym wielozadaniowym mandatem, zdecydowanie przekraczają tę liczbę, co niejednokrotnie jest konsekwencją obszaru, na którym są prowadzone. Dotyczy to zwłaszcza misji w Afryce, które swoim zasięgiem obejmują duże obszary. Istotnym problemem jest natomiast zdolność sił do wykonywania powierzonych zadań. Czynnikiem wpływającym na pozytywne postrzeganie misji z pewnością jest ich widoczność, stąd główny trzon sił stanowią bataliony piechoty zmechanizowanej, które nie wymagają specjalistycznego przeszkolenia czy wyposażenia. W praktyce jednak

4 Informacje na temat zaangażowania państw w misje pokojowe NZ aktualizowane są w cyklu miesięcznym. Zob. Peacekeeping Operational Fact Sheet, „United Nations Peacekeeping" [online, dostęp: 1 IX 2019], dostępne w internecie: $<$ https://peacekeeping un.org/en/data-0>. Arkusze operacyjne operacji pokojowych zob. Data, „United Nations Peacekeeping" [online, dostęp: 1 IX 2019], dostępne w internecie: $<$ https://peacekeeping. un.org/en/data-0>.

5 Strona internetowa Departamentu Operacji Pokojowych: Department of Peace Operations, „United Nations Peacekeeping” [online, dostęp: 1 IX 2019], dostępny w internecie: $<$ https://peacekeeping.un.org/en/department-of-peacekeeping-operations $>$. W najnowszym zestawieniu uwzględniony zostanie dwustuosobowy polski batalion skierowany do sił pokojowych UNIFIL, co z pewnością przyczyni się do awansu Polski w rankingu państw zaangażowanych w operacje pokojowe NZ. 
i one nie spełniają wymagań stawianych przez NZ wobec tego typu formacji, a tym samym ich zdolności do realizowania mandatów misji są ograniczone.

Wobec wyzwań stojących przed współczesnymi misjami pokojowymi brak skuteczności w działaniu, należytego wyszkolenia i wyposażenia skutkuje dużą liczbą ofiar wśród żołnierzy. W latach 2013-2017 ginęło ich średnio 120 rocznie, przy czym coraz częściej przyczyną śmierci były ataki na siły pokojowe, a nie choroby czy wypadki w trakcie służby ${ }^{6}$.

Jeżeli chodzi o finansowanie operacji pokojowych, to największe obciążenia ponoszą państwa będące stałymi członkami $\mathrm{RB}$, które $\mathrm{z}$ racji decydowania o tworzeniu i funkcjonowaniu misji płacą wyższe składki w ramach specjalnego budżetu na ten cel. W pierwszej dziesiątce płatników znajdują się również Japonia, Niemcy, Włochy, Kanada i Hiszpania. Składka Stanów Zjednoczonych oraz państw Unii Europejskiej to 85 proc. budżetu, podczas gdy wszystkich państw Afryki - nieco ponad 2 proc. $^{7}$ Siły delegowane przez głównych płatników stanowią natomiast zaledwie 7 proc. wszystkich kontyngentów, ale do niedawna było to tylko ok. 4 proc. Sytuacja zmieniła się w związku z ekspansją gospodarczą Chin w Afryce i przeorientowaniem ich polityki względem tego kontynentu, gdzie prowadzonych jest obecnie najwięcej operacji pokojowych NZ. Pekin zwiększył swoje zaangażowanie w tego typu operacje i według stanu na 1 września 2019 r. z 2151 żołnierzami i policjantami zajmuje pod względem delegowanych sił jedenastą pozycję. Decyzję o zwiększeniu udziału w misjach NZ podjęło też wiele państw zachodnich - przede wszystkim Niemcy, ale także Holandia, Szwecja, Finlandia i Portugalia, a zapowiedziała to również Kanada. Szczególny jest przypadek Stanów Zjednoczonych i Rosji, które wzajemnie blokują swoje zaangażowanie, w związku z czym delegują obecnie na misje odpowiednio 58 i 95 osób. Państwa zachodnie muszą jednak zaangażować siły wyspecjalizowane ${ }^{8}$, i to w rejonach najtrudniejszych - zarówno pod względem klimatu, jak i bezpieczeństwa9 .

6 M.E. Henke, Has UN Peacekeeping become more deadly? Analyzing trends in UN fatalities, International Peace Institute, New York 2016 (Providing for Peacekeeping, 14).

$7 \quad$ Polska płaci na budżet operacji pokojowych składkę w wysokości ponad $80 \mathrm{mln}$ zł.

8 Zob. deklaracje państw zgłoszone lub potwierdzone w 2017 r. podczas konferencji ministrów obrony w Vancouver: Pledges, „Gouvernment of Canada” [online, dostęp: 1 IX 2019], dostępne w internecie: <https://www.canada.ca/en/department-national-defence/ campaigns/peacekeeping-defence-ministerial/pledges.html $>$.

9 J. Karlsrud, A.C. Smith, Europe's return to UN Peacekeeping in Africa? Lessons from Mali, International Peace Institute, New York 2015 (Providing for Peacekeeping, 11). 


\section{Tworzenie operacji pokojowych NZ - proces decyzyjny}

Podejmowanie decyzji o ustanowieniu misji NZ jest procesem kompleksowym, składającym się z szeregu formalnych i nieformalnych konsultacji. Oficjalnie rozpoczyna go przyjęcie przez RB rezolucji ustanawiającej misję. W praktyce jednak pewne działania podejmowane są już wcześniej. Gdy stwierdzone zostanie pogorszenie się sytuacji bezpieczeństwa w danym miejscu na świecie, Sekretariat NZ prowadzi konsultacje, w których głównymi aktorami są Departament Spraw Politycznych i Budowania Pokoju (Department of Political and Peacebuilding Affairs, DPPA) oraz Departament Operacji Pokojowych (Department of Peace Operations, DPO). Sekretarz generalny może wystąpić z prośbą o dokonanie analizy strategicznej (strategic assessment) celem określenia możliwości i formy zaangażowania NZ. W przypadku stwierdzenia, że jedyną opcją zażegnania lub zakończenia konfliktu jest powołanie operacji pokojowej, specjalnie przygotowane zespoły do analizowania środowiska bezpieczeństwa (Integrated Operational Teams, ITO) pod przewodnictwem zastępcy sekretarza generalnego NZ ds. operacji pokojowych dokonują technicznej analizy możliwości skierowania sił pokojowych NZ $\mathrm{w}$ dany rejon (technical assessment mission). Zawiera ona opis stanu bezpieczeństwa, sytuacji politycznej, wojskowej, humanitarnej, przestrzegania praw człowieka oraz innych elementów istotnych dla funkcjonowania misji. Jest też podstawą do sporządzania przez sekretarza generalnego raportu dla $\mathrm{RB}$, który zawiera propozycje zaangażowania, wskazując zalecany rozmiar misji, zakres zadań, potrzeby logistyczne i szacunkowe koszty operacji.

W przypadku przyjęcia przez RB rezolucji o utworzeniu misji NZ konieczne jest uzyskanie aprobaty Zgromadzenia Ogólnego co do jej szacowanego budżetu. Jako pierwsze powoływane jest kierownictwo misji. Obecnie, ze względu na zakres mandatu, który wykracza poza działania typowo wojskowe, stanowisko szefa misji w randze specjalnego przedstawiciela sekretarza generalnego NZ przydzielane jest osobie cywilnej (Special Representative Secretary General, SRSG). Poza tym powołuje się głównodowodzącego siłami wojskowymi (Force Commander) oraz szefa sił policyjnych (Police Commissioner), a także personel cywilny. W misjach, gdzie zadania mandatowe są wyłącznie albo w większości typowo wojskowe, SRSG mianuje się głównodowodzącego siłami wojskowymi.

Sekcja Planowania (Mission Planning Service, MPS) Departamentu Operacji Pokojowych, działając na podstawie określonej rezolucji RB, 
opracowuje w oparciu o analizę techniczną koncepcję misji (mission concept of operations, CONOPS). Dokument ten precyzuje strukturę misji: liczbę pododdziałów, oficerów sztabowych, obserwatorów wojskowych, na podstawie czego precyzuje się szczegółowe wymogi dla sił (statement of force requirement, SFR). Określa się $\mathrm{w}$ nich typ i liczbę pododdziałów, przypisane im działania i zakres zdolności niezbędnych do rozpoczęcia misji, za co odpowiedzialny jest Departament Wsparcia Operacyjnego (Department of Operational Support, DOS), a także listę wyposażenia pozwalającego na skuteczne wykonywanie mandatu. To po dokonaniu tych czynności powinien się rozpocząć proces generacji sił, czyli poszukiwania personelu mającego odpowiednie zdolności do wypełnienia zadań określonych w mandacie operacji. W rzeczywistości jednak działania te, podobnie jak podejmowanie decyzji o ustanowieniu operacji pokojowej, zaczynają się o wiele wcześniej. Ze względu na złożoność procesu wydzielania sił, niejednokrotnie uzależnionego od wewnętrznych uregulowań prawnych zainteresowanych państw, nieformalnego wyboru dokonuje się już wówczas, gdy podjęcie decyzji o utworzeniu misji NZ staje się prawdopodobne. DPO musi mieć świadomość, jakimi siłami może dysponować w przypadku konkretnej misji. Proces generacji sił nie ogranicza się zatem do ich ostatecznego wyselekcjonowania, ale polega również na permanentnej analizie ich zdolności do realizowania zadań mandatowych.

\section{System generacji sil}

Choć początkowo proces generacji sił pokojowych NZ był nieusystematyzowany i chaotyczny, to jednak cechowały go wydolność i skuteczność. Na przykład w 1956 r. wydzielenie sił do misji w Suezie zajęło 7 dni, wydzielenie pierwszych 3000 żołnierzy do misji w Kongu w 1969 r. - 3 dni, a po wybuchu konfliktu między Egiptem a Izraelem w 1973 r. pierwsi żołnierze pojawili się w jego rejonie już po 17 godzinach $^{10}$. Wobec coraz większej aktywności NZ zaistniała jednak konieczność stworzenia systemu, który pozwoliłby wyselekcjonować, a następnie skierować odpowiednie siły do realizacji określonego mandatu misji w jak najkrótszym czasie od podjęcia decyzji o jej powołaniu przez RB.

10 A.C. Smith, A. Boutellis, Rethinking force generation. Filling the capability gaps in UN Peacekeeping, International Peace Institute, New York 2013 (Providing for Peacekeeping, 2), s. 3 . 
W 1992 r. sekretarz generalny NZ zapowiedział reformę dyplomacji prewencyjnej, operacji pokojowych oraz operacji wymuszania pokoju ${ }^{11}$, a jednocześnie wystąpił z inicjatywą utworzenia systemu generacji sił do misji pokojowych NZ. Powstały w 1994 r. United Nations Standby Arrangements System (UNSAS) miał za zadanie usprawnić zarządzanie zasobami ludzkimi i sprzętowymi. W 1995 r., w odpowiedzi na suplement do raportu sekretarza generalnego, RB jasno określiła, że w podnoszeniu zdolności do szybkiego przemieszczenia sił w rejon misji priorytetowo należy potraktować dalsze wzmacnianie systemu ich generacji, który powinien obejmować spektrum zasobów niezbędnych do realizowania mandatu ${ }^{12}$.

W 2000 r. opublikowano raport na temat funkcjonowania operacji pokojowych, zwany od nazwiska przewodniczącego panelu ekspertów raportem Brahimiego ${ }^{13}$. Wyraźnie stwierdzono w nim, że niejednokrotnie siły deklarowane przez państwa nie spełniają minimalnych standardów określonych dla konkretnych pododdziałów przez NZ, a tym samym państwa nie mogą wypełnić składanych deklaracji i wydzielić sił, które byłyby zdolne zrealizować mandat określony przez RB. Po opublikowaniu raportu przystąpiono zatem do opracowania bazy danych i budowania systemu pozwalającego na wydzielenie sił, które będą zdolne do realizacji powierzanego mandatu.

System miał spełniać cztery podstawowe zadania:

- zapewnić DPO precyzyjne informacje na temat deklarowanych sił i zdolności państw do ich wydzielenia,

- usprawnić system planowania i generowania sił w celu wsparcia identyfikacji odpowiednich zasobów gotowych do przemieszczenia,

- poszerzyć spektrum możliwości planowania odnośnie do kierowania sił na misje oraz wsparcia ich szybkiego przemieszczenia,

- zachęcić państwa wydzielające siły do większej aktywności, a jednocześnie określić struktury ewentualnych pododdziałów, wymagania sprzętowe i niezbędny poziom wyszkolenia ${ }^{14}$.

UNSAS zakładał deklarowanie przez poszczególne państwa chęci uczestniczenia w operacji, którego konsekwencją powinno być oddanie odpowiednich

11 An Agenda for Peace, United Nations Secretary-Generally, A/47/277, 17 VI 1992, dostępny w internecie [dostęp: 1 IX 2019]: <http://www.un-documents.net/a47-277.htm>.

12 Statement by the President of the Security Council, United Nations Security Council, S/PRST/1995/9, 22 II 1995, s. 2.

13 Report of the panel on United Nations peace operations (Brahimi report), United Nations General Assembly, Security Council, A/55/305, S/2000/809, 21 VIII 2000.

14 H.P. Langille, Improving United Nations capacity for rapid deployment, International Peace Institute, New York 2014 (Providing for Peacekeeping, 8), s. 5. 
zasobów w czasie uzgodnionym przez strony. Wyszczególnione zostały cztery poziomy deklaracji:

- pierwszy, polegający na przedstawieniu listy zdolności, tj. wielkości deklarowanych sił oraz ich siły bojowej ze wskazaniem terminu gotowości do zaangażowania;

- drugi, polegający na zadeklarowaniu szczegółowej listy wyposażenia pododdziału wraz ze szczegółowym opisem jego struktury i poziomu samowystarczalności;

- trzeci, polegający na negocjacji i zawarciu porozumienia między Sekretariatem NZ a państwem (Memorandum of Understanding, MoU), zawierającego szczegółowe dane na temat zdolności i zasobów ${ }^{15}$;

- czwarty, polegający na zadeklarowaniu sił szybkiej gotowości (tzw. Rapid Deployment Level), czyli zapewnieniu, że zadeklarowany oddział będzie gotowy do skierowania w rejon misji w terminie 30 lub 90 dni od uchwalenia mandatu $\mathrm{RB}^{16}$.

W styczniu 2013 r. do systemu UNSAS zgłoszonych było 90 ze 117 państw uczestniczących wówczas w operacjach pokojowych NZ. Poziom I zadeklarowały 23 z nich, poziom II -7 , poziom III -57 , a poziom IV -3 . Do systemu zgłoszono: 46 batalionów piechoty, 3 bataliony inżynieryjne, 25 kompanii inżynieryjnych, 29 helikopterów, 9 szpitali poziomu drugiego - w sumie 108400 żołnierzy ${ }^{17}$. UNSAS obejmował zarówno pododdziały zwarte, jak i samodzielnych żołnierzy działających w charakterze doradców, obserwatorów wojskowych lub oficerów sztabowych, ale już nie siły policyjne.

Stworzenie procesu służącego do generacji sił było koniecznością, zważywszy na fakt, do jakich rozmiarów wzrosły obecnie siły określane w mandatach RB. Opierał się on jednak na szeregu błędnych założeń, które nie sprawdziły się w praktyce.

UNSAS wymagał od państw deklaracji, które często odbiegały od rzeczywistych potrzeb misji. Państwa proponowały np. siły, które ze względu na zakres mandatu operacji nie były brane pod uwage przy generacji sił.

15 Polska przystąpiła do systemu UNSAS w 2003 r., deklarując gotowość wysłania batalionu zmechanizowanego oraz obserwatorów.

16 W kwestiach szczególowych zob. The Rapid Deployment Level of the Peacekeeping Capability Readiness System, United Nations Department of Peace Operations, United Nations Department of Operational Support, 2019, dostępny w internecie [dostęp: 1 IX 2019]: <https://pcrs.un.org/Lists/Announcements/Attachments/18/2019.02\%20The\%20 Rapid\%20Deployment\%20Level\%20of\%20the\%20Peacekeeping\%20Capability\%20 Readiness\%20System_Guidelines.pdf?Mobile $=1>$.

17 H. Langille, Improving United Nations capacity..., s. 5. 
W większości też, mimo znacznej liczebności, nie miały zdolności do wykonania mandatu. W praktyce pomimo swoich deklaracji, weryfikowanych przez Sekretariat NZ podczas wizyt i inspekcji, państwa nie były w stanie zapewnić stosownych zdolności do misji. Wszystko to powodowało, że system był nietransparentny, a składane zobowiązania - zbyt ogólne i niedostosowane do konkretnych potrzeb. Aby to zmienić, wprowadzono wymóg potwierdzania złożonych deklaracji co dwanaście miesięcy, ale w praktyce realizowany był on jedynie przez państwa, które uczestniczyły w operacjach, i w odniesieniu do zaangażowanych sił. Generacji sił nie ułatwiał też mechanizm podejmowania decyzji przez RB. Choć formalnie wybór państw uczestniczących w operacji bazował na UNSAS, to w rzeczywistości zależał od wiedzy oficerów z Biura Spraw Wojskowych i uwarunkowań politycznych, podczas gdy kwestie zdolności sił do realizacji mandatu schodziły na dalszy plan.

UNSAS nie spełnił więc pokładanych w nim oczekiwań. Pomimo usprawnienia w 2010 r. poprzez digitalizację danych i wprowadzenie możliwości elektronicznego składania deklaracji przez cały czas funkcjonowania systemu (tj. do września 2015 r.) dokonano jedynie ok. 100 zgłoszeń, z czego w 2015 r. potwierdzono zaledwie 13. Niesprawność systemu generacji sił (w tym konsekwentnego potwierdzania ich gotowości) powodowała, że odbywała się ona całkowicie poza nim, natomiast poziom przygotowania zgłaszanych sił był nieadekwatny do potrzeb, a mimo to akceptowany, co miało negatywny wpływ na realizację mandatów misji ${ }^{18}$.

W związku z sugestiami Niezależnego Panelu Wysokiego Szczebla ds. Operacji Pokojowych ${ }^{19}$ Sekretariat NZ przystąpił do prac nad przygotowaniem nowego systemu generacji sił. W ramach Force Generation Service DPO powołano więc komórkę ds. zaprojektowania i wdrożenia UN Peacekeeping Capabilities Readiness System (PCRS).

Nowy system działa od września 2015 r., a jego zadaniem jest poprawa efektywności zarządzania zadeklarowanymi siłami, osiągnięcie większego

18 W szczególności dotyczyło to nowo tworzonych misji w Afryce. Często generacja sił polegała na przejęciu przez NZ misji regionalnych, których siły nie spełniały minimalnych standardów określanych przez NZ. Zob. np. misje: MINUSCA w Republice Środkowoafrykańskiej, MONUSCO w Kongu czy UNMISS w Sudanie Południowym. Operacje te mają bardzo szeroki mandat, wykraczający poza klasyczne działania utrzymywania pokoju, jak w przypadku misji z lat wcześniejszych, np. UNIFIL w Libanie czy UNDOF na pograniczu Izraela i Syrii.

19 Report of the High-Level Independent Panel on Peace Operations on uniting our strengths for peace: politics, partnership and people, United Nations General Assembly, Security Council, A/70/95, S/2015/446, 17 VI 2015. 
poziomu ich gotowości, koordynacja współpracy między państwami a NZ oraz wprowadzenie jednolitego i spójnego systemu selekcji państw deklarujących siły. Obejmuje on zarówno zwarte pododdziały, jak i samodzielny personel wojska i innych służb, w tym policji (doradców, obserwatorów i oficerów sztabowych).

Podobnie jak UNSAS PCRS zakłada cztery poziomy zobowiązań państw, ale nowością jest powiązanie ich ze sobą. Przejście do poziomu wyższego możliwe jest tylko przy spełnieniu wymagań na wcześniejszych.

Poziom I to formalne zadeklarowanie sił, precyzujące ich strukturę organizacyjną, listę głównego wyposażenia i samowystarczalność do czasu zapewnienia odpowiedniego wyposażenia przez NZ (self-sustainment), a także potwierdzenie odbycia niezbędnego do realizowania misji szkolenia podstawowego ${ }^{20}$.

Przejście na poziom II oznacza pozytywne zweryfikowanie przez DPO deklaracji z poziomu I ${ }^{21}$. Zaakceptowanie zdolności zadeklarowanych sił na poziomie II będzie usankcjonowane zawarciem wstępnego porozumienia - zbliżonego $\mathrm{w}$ formie do MoU z poziomu III UNSAS, ale z zadeklarowaniem konkretnych zasobów osobowych i sprzętowych.

Poziom III to zawarcie porozumienia między Sekretariatem NZ a państwem chcącym wziąć udział w operacji. Obejmuje ono wszystkie dane związane $\mathrm{z}$ wydzieleniem samodzielnego personelu lub pododdziału, w tym listę sprzętu zgodnie z Contingent Owned Equipment (procedurą zwrotu kosztów udziału w operacji pokojowej NZ) oraz listę załadunkową wymaganą przez Departament Wsparcia Operacji.

Poziom IV (Rapid Deployment Level) nie jest jak dotychczas wyłącznie deklaracją możliwości skierowania sił w terminie 90 dni od uchwalenia mandatu operacji. Zawiera zgłoszenie, które pomyślnie przeszło poziomy I, II i III, oraz deklarację wydzielenia sił w terminie 30, 60 lub 90 dni od uchwalenia mandatu. $\mathrm{W}$ przypadku wydzielenia takich sił państwo będzie dodatkowo wynagradzane ${ }^{22}$.

20 W celu zapoznania państwa strony z nowym systemem Sekretariat NZ rozpowszechniał liczne materiały informujące o sposobie dokonywania nowych zgłoszeń. Na temat kwestii technicznych zgłoszeń zob. PCRS Member State Guide Peacekeeping Capability Readiness System, United Nations Department of Field Support, grudzień 2018, dostępny w internecie [dostęp: 1 IX 2019]: <https://pcrs.un.org/_layouts/15/mobile/viewa.aspx?List=2f346e67\%2Dff86\%2D44f2\%2D9242\%2D0022ddd6df62\&View=ba3b3224\%2D08c9\%2D4d00\%2D89 7f\%2D85d87221488c\&RootFolder=\%2FLists\%2FResources\%2FPCRS\%20Website >.

21 Polska dokonała zgłoszenia do systemu PCRS notą dyplomatyczną SP.ONZ. NJO.2551.51.2016 z 4 X 2016 r., zapewniając liczący do 50 osób pododdział inżynieryjny oraz gotowość skierowania do misji NZ 30 obserwatorów wojskowych, doradców wojskowych albo oficerów sztabowych.

The Rapid Deployment Level... 
Sekretariat NZ wprowadził certyfikowanie zdolności sił przed wpisaniem na kolejny poziom w PCRS. Odbywa się to poprzez przeprowadzenie w poszczególnych państwach wizyt oceniająco-doradczych (assessment and advisory visit, AAV), których celem jest sprawdzenie zdolności zgłoszonych pododdziałów do wykonywania zadań w ramach misji pokojowych NZ oraz ocena sposobu szkolenia i przygotowania sprzętowe$\mathrm{go}^{23}$. AAV pełnią również rolę doradczą - niezwykle istotną w przypadku nowych państw chcących uczestniczyć w misjach NZ albo rozważających powrót do uczestnictwa w operacjach pokojowych po dłuższej przerwie. $\mathrm{W}$ trakcie wizyty przedstawiane są procedury i regulacje obowiązujące w systemie NZ, kwestie logistyczne (dotyczące m.in. wydzielania sprzętu i sposobów refundacji uczestnictwa), zagadnienia związane z wykonywaniem mandatu, sprawy dyscyplinarne (ze szczególnym uwzględnieniem problemu wykorzystywania seksualnego) oraz problematyka przestrzegania praw. Przeprowadzenie takiej wizyty jest konieczne, by zadeklarowane siły mogły zostać zakwalifikowane do kolejnego poziomu. Z uwagi na ograniczone fundusze planuje się je jednak tak, by weryfikowały przede wszystkim takie jednostki, które są najbardziej potrzebne w rejonie działania misji ${ }^{24}$. Do takich należą m.in. deklaracje wydzielenia śmigłowców, sił szybkiego reagowania, sekcji rozpoznawczych i analizy informacji ${ }^{25}$. Należy zaznaczyć, że w pierwszej kolejności certyfikowano pododdziały, które uczestniczą już w operacjach pokojowych NZ.

Wobec różnych potencjałów zdolności sił wojskowych i policyjnych poszczególnych państw odstąpiono od sztywnego określania sił i środków, jakimi musi dysponować dany pododdział. Zamiast tego opracowano

23 Wobec zadeklarowania przez Polskę chęci uczestnictwa w misji pokojowej na Bliskim Wschodzie w lutym 2019 r. doszło do wizyty przedstawicieli Sekretariatu NZ w wytypowanych do tego jednostkach wojskowych. W związku z pozytywną oceną AVV zaproponowano Polsce skierowanie sił do misji UNIFIL. Żołnierze uczestniczą w tej operacji od listopada 2019 r., a jeszcze przed wyjazdem, w dniach 2-5 września, Sekretariat dokonał inspekcji wysyłanego poddziału, a pozytywna ocena stała się podstawą do wyjaz$\mathrm{du}$ w rejon działania.

$24 \mathrm{~W}$ pierwszym roku funkcjonowania systemu przeprowadzono ponad $40 \mathrm{AAV}$, w ramach których dokonano oceny ponad 100 pododdziałów zgłoszonych do PCRS. Oświadczenie zastępcy sekretarza generalnego NZ ds. operacji pokojowych Jeana-Pierre'a Lacroix wygłoszone w trakcie debaty nt. operacji pokojowych NZ zorganizowanej 5 X $2017 \mathrm{r}$. w RB: Strategic force generation, United Nations Security Council, S/PV.8064, dostępny w internecie [dostęp: 1 IX 2019]: <https://www.securitycouncilreport.org/atf/cf/\%7B65BFCF9B-6D27-4E9C-8CD3-CF6E4FF96FF9\%7D/s_pv_8064.pdf $>$.

25 Informacje o istotnych brakach przekazywane są kwartalnie do stałych przedstawicielstw przy NZ. 
przewodniki, które określają minimalne wymagania sprzętowe i bojowe wobec poszczególnych formacji ${ }^{26}$.

Nieco odmienne założenia przyjęto $\mathrm{w}$ odniesieniu do sił policyjnych. Z uwagi na mniejszą różnorodność pododdziałów i mniejszą dysproporcję potencjałów między poszczególnymi państwami, a także sztywne i egzekwowane przez Sekretariat NZ standardy, wskazano konkretne struktury (wraz z listą uzbrojenia i sprzętu), które będą podlegały weryfikacji:

- sformowane oddziały policji (Formed Police Units),

- wyspecjalizowane jednostki lub sekcje policji (SWAT Unit/Team),

- policyjne siły ochrony (Police Guard Teams).

Zgodnie z założeniami systemu pierwsze zgłoszenie obowiązuje przez dwanaście miesięcy, po czym powinno być odnawiane co pół roku. Zarówno zgłoszenia deklaracji, jak i jej odnowienia dokonuje się w formie noty dyplomatycznej ${ }^{27}$. Każde zgłoszenie powinno zawierać załączniki określające strukturę pododdziału, listę podstawowego sprzętu na jego wyposażeniu ( $m a-$ jor equipment) oraz wyposażenia mającego zapewnić samowystarczalność do czasu przejęcia odpowiedzialności za utrzymanie logistyczne pododdziatu przez NZ (self-sustaiment equipment). Dodatkowo korespondencja powinna zawierać informacje o ograniczeniach narodowych (national caveats), począwszy od kwestii związanych z metodami i środkami wykorzystywanymi w trakcie operacji, a skończywszy na politycznych ograniczeniach zaangażowania uzależnionych od obszaru działania czy stron konfliktów.

W ramach PCRS można również deklarować inne wsparcie, np. możliwość wydzielenia statków powietrznych w ramach cywilnych kontraktorów czy zapewnienia zdolności szkoleniowych lub sprzętowych dla przyszłych sił pokojowych ${ }^{28}$.

26 Departament Operacji Pokojowych wspólnie z Departamentem Wsparcia Operacji opracował takie przewodniki dla kilkunastu struktur, m.in. pododdziałów łączności, logistyki, inżynieryjnych, wsparcia kwatery, policji wojskowej, rzecznych, transportowych, morskich, sił specjalnych i batalionów zmechanizowanych. Można je znaleźć w zasobach biblioteki NZ: „Dag Hammarskjöld Library” [online, dostęp: 1 IX 2019], dostępny w internecie: <http://dag.un.org>.

27 Polska odnowiła swoje zgłoszenie notą dyplomatyczną SP.ONZ.NJO.2551.69.2017 z 13 X 2017 r.

28 Deklaracje takie składane były na organizowanych przez NZ szczytach dotyczących operacji pokojowych, a następnie wpisywane do systemu PCRS. 


\section{Inicjatywy państw w kwestii poprawy systemu generacji sil}

Zakres mandatu udzielanego siłom pokojowym NZ zależy od natury konfliktów, które obecnie coraz częściej mają charakter niemiędzynardowy lub transgraniczny i dotyczą lokalnych lub plemiennych ugrupowań, często o charakterze przestępczym, a nawet terrorystycznym. Liczne nowe zadania nie przystają do powszechnych wyobrażeń na temat działań mających na celu utrzymanie pokoju, w związku z czym powstały problemy z generowaniem zdolnych do ich realizacji sił. Problem ten stał się przyczyną zapoczątkowania w NZ zakrojonej na dużą skalę inicjatywy politycznej, która ma na celu uświadomienie decydentom problemów z realizacją mandatów przez siły pokojowe. Państwa, których wkład finansowy jest największy, coraz częściej wyrażają niezadowolenie ze sposobu wykonywania mandatów i propagują konieczność dokonania fundamentalnych reform w systemie operacji pokojowych, twierdząc, że obecnie wydzielone siły, ich struktura i wyposażenie nie gwarantują realizacji powierzonych zadań. Państwa, które uczestniczą w obecnych misjach pokojowych (w większości rozwijające się), tłumaczą istniejący kryzys nieprawidłowym finansowaniem misji oraz tym, że RB nie konsultuje z nimi mandatów operacji ${ }^{29}$.

W 2014 r. zapoczątkowano spotkania na wysokim szczeblu dotyczące operacji pokojowych NZ. Pierwsze dwa, na poziomie głów państw, zorganizowane zostały przez Stany Zjednoczone: w 2014 r. pod przewodnictwem wiceprezydenta Joe Bidena, a w 2015 - prezydenta Baracka Obamy ${ }^{30}$. Kolejne, na poziome ministrów obrony, odbyły się w 2016 r. w Londynie ${ }^{31}$ oraz w 2017 w Vancouver ${ }^{32}$. Głównym celem tych szczytów było zachęcenie państw do deklarowania większego zaangażowania oraz dywersyfikacji zdolności, a poza tym wzmocnienie

29 Wystąpienia państw w ramach debaty podczas prac Specjalnego Komitetu ds. Operacji Pokojowych NZ zob. C-34 2019 Substansive Session, „United Nations Paper Smart” [online, dostęp: 1 IX 2019], dostępny w internecie: <https://papersmart.unmeetings.org/ga/ special-committee-on-peacekeeping-operations-(c-34)/c-34-2019-substansive-session/ statements>.

302015 Leader's Summit on Peacekeeping Summary of Member State Commitments, United Nations, October 2015.

31 UN Peacekeeping Defence Ministerial London 2016. Report of the meeting 7-8 September, 2016, Ministry of Defence, dostępny w internecie [dostęp: 1 IX 2019]: <https:// www.gov.uk/government/publications/un-peacekeeping-defence-london-ministerial2016-report-of-the-meeting>.

32 Komunikat z konferencji „Vancouver Communique”: Communique, „Government of Canada" [online], 11 I 2018 [dostęp: 1 IX 2019], dostępny w internecie: <https://www. canada.ca/en/department-national-defence/campaigns/peacekeeping-defence-ministe$\mathrm{rial} /$ news/communique.html $>$. Dokonane lub potwierdzone zgłoszone zobowiązania do systemu PCRS: Pledges... 
świadomości znaczenia operacji pokojowych NZ w rozstrzyganiu konfliktów na świecie. Pierwsze deklaracje państw w 2015 r. zaskoczyły swoim rozmiarem organizatorów, jednak dość szybko okazało się, że większość zobowiązań nie znajduje odzwierciedlenia w rzeczywistości. Weryfikacja zobowiązań w ramach PCRS spowodowała, że w kolejnych zgłoszeniach deklaracje poszczególnych państw były bardziej rozsądne. Konferencja w Londynie pokazała, że możliwości sił, którymi mogą dysponować NZ, są ograniczone, a przede wszystkim nie odpowiadają potrzebom misji. Państwa deklarowały głównie bataliony piechoty, które mimo swej liczebności w praktyce mogłyby się okazać niezdolne do realizacji mandatu. $Z$ tego powodu konferencje w Londynie i Vancouver, oprócz części dotyczącej możliwości zgłaszania zobowiązań oraz ich weryfikacji, wykorzystano do uświadomienia państw w kwestii wyzwań stojących przed wydzielanymi siłami we współczesnych misjach NZ.

Szczególna uwaga zwrócona została na kwestie ochrony praw człowie$\mathrm{ka}$, uczestnictwa kobiet $\mathrm{w}$ misjach pokojowych, ochrony ludności cywilnej oraz bezpieczeństwa wykonawców zadań mandatowych. Istotnym elementem prawidłowego prowadzenia misji jest zachowanie dyscypliny, w szczególności wobec problemu seksualnego wykorzystywania społeczności lokalnej przez siły pokojowe. W dyskusji podniesiono też problemy konieczności kierowania do misji sił wyposażonych w lepszy sprzęt, zapewnienia im większej mobilności oraz wprowadzania nowych technologii.

5 października 2017 r. z inicjatywy Francji i Wielkiej Brytanii zorganizowano debatę RB nt. strategicznej generacji sił. Szef DPO zwrócił wówczas uwagę, że rotacja ponad 300 pododdziałów składających się z tysięcy żołnierzy z ponad 120 krajów jest wyzwaniem dla każdej struktury.

Według danych, które w trakcie debaty przekazał Sekretariat NZ, w PCRS zarejestrowano 81 państw. Skompletowana została brygada szybkiego reagowania Vanguard Brigade składającą się z 4 tys. żołnierzy i policjantów. Niestety, wciąż wskazuje się na problemy z generacją wyspecjalizowanych pododdziałów, takich jak zespoły śmigłowców, siły szybkiego reagowania czy zespoły rozminowania ${ }^{33}$.

\section{Wnioski}

Chęć zapobieżenia konfliktom, z którymi wcześniej społeczność międzynarodowa nie miała do czynienia, spowodowała, że w ostatnich dziesięciu latach

33 Sprawozdanie z debaty „United Nations peacekeeping operations”: Strategic force generation... 
nastąpił dziesięciokrotny wzrost zaangażowania sił pokojowych NZ. Nie pozostało to jednak bez wpływu na jakość wykonywania mandatu, która była pochodną generowania do misji sił nieodpowiadających stawianym im zadaniom. Charakter konfliktów oraz obszary, na których się toczą, wymagają delegowania wysoce wyspecjalizowanych, mobilnych, a jednocześnie licznych sił. UNSAS nie nadążył za tymi wyzwaniami, natomiast późniejszy PCRS przyczynił się do stworzenia aktualnej bazy możliwych do zaangażowania sił i środków, których gotowość została zweryfikowana przez Sekretariat NZ.

Usprawnienie systemu generacji sił należy uznać za niezwykle pożądane działanie. Na wyróżnienie zasługuje zmiana podejścia do oceny zdolności sił. Wprowadzenie certyfikacji przed zakwalifikowaniem ich do wyższego poziomu w systemie z pewnością przyczynia się do urealnienia deklaracji poszczególnych państw.

Z przykrością należy stwierdzić, że wiele państw wciąż nie spełnia niewygórowanych standardów $\mathrm{NZ}^{34}$, co powoduje, że zachodni przywódcy z nieufnością odnoszą się do potencjalnej współpracy z nimi w ramach misji pokojowych. Co prawda coraz częściej wykazują oni chęć większego zaangażowania w koalicjach, ale wciąż szukają sojuszników wśród państw mogących zapewnić pododdziały o podobnym wyszkoleniu i standardach sprzętowych ${ }^{35}$. Paradoksalnie problemem jest też fakt, że lepiej wyszkolone i wyposażone jednostki zachodnie niejednokrotne nie wpisują się w standardy NZ, które oczekują pododdziałów o dużej liczebności ${ }^{36}$.

Należy wyraźnie podkreślić, że zgłoszenie w ramach PCRS nie ma charakteru wiążącego i nie rodzi automatycznego obowiązku wydzielenia zadeklarowanych sił. Ostateczne postanowienie o zaangażowaniu w daną misję jest suwerenną decyzją każdego z państw. Dodatkowo każda deklaracja może zawierać zastrzeżenia odnoszące się np. do rodzaju operacji, formy wykonywanych działań, obszaru geograficznego, wykorzystania konkretnych sił i środków, preferencji językowych, kulturowych czy możliwości współpracy

34 Pokazują to raporty okresowe z misji, w szczególności na kontynencie afrykańskim, gdzie większość sił stanowią wojska państw rozwijających się, głównie z Afryki i Azji. Można je znaleźć na stronie: „United Nations Peacekeeping” [online, dostęp: 1 IX 2019], dostępna w internecie: <https://peacekeeping.un.org/en>.

35 A. Boutellis, J. Karlsrud, Plug and play. Multinational rotation contributions for UN peacekeeping operations, International Institute of Foreign Affairs, Oslo 2017.

$36 \mathrm{Na}$ przykład standardowy batalion piechoty zmotoryzowanej powinien się składać z 800 żołnierzy, ale państwa zachodnie uzyskują zdolności do wykonywania działań określonych mandatem NZ dla batalionu zmechanizowanego, wystawiając jednostkę w sile 350 osób. Wynika to z lepszego wyszkolenia i wyposażenia pododdziałów. 
z konkretnymi państwami. Ewentualne zastrzeżenia zmniejszają oczywiście możliwość zaproszenia do udziału w operacji.

Mimo znacznego postępu w prowadzeniu operacji pokojowych NZ nadal zauważalne są braki w niszowych specjalnościach. Przy wyborze sił do udziału w misjach większą rolę odgrywają wciąż uwarunkowania polityczne aniżeli należyte przygotowanie do wykonywania zadań mandatowych. Nie negując czynników politycznych, należy mieć nadzieję, że wprowadzanie opartego na przejrzystych kryteriach systemu generacji sił PCRS przyczyni się do poprawy efektywności funkcjonowania misji pokojowych NZ.

\section{Bibliografia}

\section{Literatura}

Bellamy A.J., Williams P.D., Broadening the base of United Nations troop- and police-contributing countries, International Peace Institute, New York 2012 (Providing for Peacekeeping, 1).

Boutellis A., Karlsrud J., Plug and play. Multinational rotation contributions for UN peacekeeping operations, International Institute of Foreign Affairs, Oslo 2017.

Department of Peace Operations, „United Nations Peacekeeping” [online, dostęp: 1 IX 2019], dostępny w internecie: <https://peacekeeping.un.org/en/department-of-peacekeeping-operations $>$.

Henke M.E., Has UN Peacekeeping become more deadly? Analyzing trends in UN fatalities, International Peace Institute, New York 2016 (Providing for Peacekeeping, 14).

Karlsrud J., Smith A.C., Europe's return to UN Peacekeeping in Africa? Lessons from Mali, International Peace Institute, New York 2015 (Providing for Peacekeeping, 11).

Langille H.P., Improving United Nations capacity for rapid deployment, International Peace Institute, New York 2014 (Providing for Peacekeeping, 8).

Smith A.C., Boutellis A., Rethinking force generation. Filling the capability gaps in UN Peacekeeping, International Peace Institute, New York 2013 (Providing for Peacekeeping, 2).

\section{Dokumenty}

2015 Leader's Summit on Peacekeeping Summary of Member State Commitments, United Nations, October 2015.

An Agenda for Peace, United Nations Secretary-Generally, A/47/277, 17 VI 1992, dostępny w internecie [dostęp: 1 IX 2019]: <http://www.un-documents.net/a47-277.htm>.

C-34 2019 Substansive Session, „United Nations Paper Smart” [online, dostęp: 1 IX 2019], dostępny w internecie: $<$ https://papersmart.unmeetings.org/ga/special-committee-on-peacekeeping-operations-(c-34)/c-34-2019-substansive-session/statements>.

Communique, „Government of Canada” [online], 11 I 2018 [dostęp: 1 IX 2019], dostępny w internecie: $<$ https:/www.canada.ca/en/department-national-defence/campaigns/peacekeeping-defence-ministerial/news/communique.html $>$.

„Dag Hammarskjöld Library” [online, dostęp: 1 IX 2019], dostępny w internecie: <http://dag. un.org>. 
Data, „United Nations Peacekeeping” [online, dostęp: 1 IX 2019], dostępne w internecie: $<$ https://peacekeeping.un.org/en/data-0>.

Nota dyplomatyczna Stałego Przedstawicielstwa RP przy NZ nr SP.ONZ.NJO.2551.51.2016 z 4 X $2016 \mathrm{r}$.

Nota dyplomatyczna Stałego Przedstawicielstwa RP przy NZ nr SP.ONZ.NJO.2551.69.2017 z 13 X 2017 r.

PCRS Member State Guide Peacekeeping Capability Readiness System, United Nations Department of Field Support, grudzień 2018, dostępny w internecie [dostęp: 1 IX 2019]: $<$ https://pcrs.un.org/_layouts/15/mobile/viewa.aspx?List=2f346e67\%2Dff86\%2D44f2\%2D9242\%2D0022ddd6df62\&View=ba3b3224\%2D08c9\%2D4d00\%2D89 $7 \mathrm{f} \% 2 \mathrm{D} 85 \mathrm{~d} 87221488 \mathrm{c} \&$ RootFolder $=\% 2 \mathrm{FLists} \% 2 \mathrm{FResources} \% 2 \mathrm{FPCRS} \% 20$ Website $>$.

Peacekeeping Operational Fact Sheet, „United Nations Peacekeeping” [online, dostęp: 1 IX 2019], dostępne w internecie: <https://peacekeeping.un.org/en/data-0>.

Pledges, „Gouvernment of Canada” [online, dostęp: 1 IX 2019], dostępne w internecie: <https:// www.canada.ca/en/department-national-defence/campaigns/peacekeeping-defence-ministerial/pledges.html>.

The Rapid Deployment Level of the Peacekeeping Capability Readiness System, United Nations Department of Peace Operations, United Nations Department of Operational Support, 2019, dostępny w internecie [dostęp: 1 IX 2019]: <https://pcrs.un.org/Lists/Announcements/ Attachments/18/2019.02\%20The\%20Rapid\%20Deployment\%20Level\%20of\%20the\%20 Peacekeeping\%20Capability\%20Readiness\%20System_Guidelines.pdf?Mobile=1>.

Report of the High-Level Independent Panel on Peace Operations on uniting our strengths for peace: politics, partnership and people, United Nations General Assembly, Security Council, A/70/95, S/2015/446, 17 VI 2015.

Report of the panel on United Nations peace operations (Brahimi report), United Nations General Assembly, Security Council, A/55/305, S/2000/809, 21 VIII 2000.

Resolutions, „United Nations Security Council” [online, dostęp: 1 IX 2019], dostępne w internecie: $<$ http://www.un.org/en/sc/documents/resolutions $>$.

Rezolucja RB NZ nr 91 z 30 III 1951 r.

Rezolucja RB NZ nr 350 z 31 V 1974 r.

Rezolucja RB NZ nr 425 i 426 z 19 III 1978 r.

Rezolucja RB NZ nr 2098 z 28 III 2013 r.

Statement by the President of the Security Council, United Nations Security Council, S/PRST/ 1995/9, 22 II 1995.

Strategic force generation, United Nations Security Council, S/PV.8064, dostępny w internecie [dostęp: 1 IX 2019]: <https://www.securitycouncilreport.org/atf/cf/\%7B65BFCF9B-6D27-4E9C-8CD3-CF6E4FF96FF9\%7D/s_pv_8064.pdf>.

UN Peacekeeping Defence Ministerial London 2016. Report of the meeting 7-8 September, 2016, Ministry of Defence, dostępny w internecie [dostęp: 1 IX 2019]: $<$ https://www.gov.uk/government/publications/un-peacekeeping-defence-londonministerial-2016-report-of-the-meeting>.

„United Nations Peacekeeping” [online, dostęp: 1 IX 2019], dostępna w internecie: <https:// peacekeeping.un.org/en>. 